\title{
Etiese perspektiewe vir die hantering van konflik in die mediese wetenskap
}

\author{
L O K Lategan
}

Universiteit van die Oranje Vrystaat

\begin{abstract}
Ethical perspectives in dealing with conflict in the medical sciences

Medical practice is daily confronted with the problem how to deal with ethical conflict. This matter becomes even more difficult when one deals with boarder-situations such as abortion and euthanasia. Here a choice is required between life and death. But it is important to bear in mind that approaching ethical situations requires knowledge of powers such as ideology, technique, etc and paradigms such as Christian anthropology which influence our decisions. Therefore, it seems that ethical models such as situation ethics and casuistry are insufficient to deal with the problem of conflict. In this paper a ethical model is presented to deal with conflict in medical ethics. This model - contextual normative ethics - tries to compromise an ethical dilemma.
\end{abstract}

\section{OP SOEK NA N METODE}

'n Belangrike winspunt van die ontwikkelings op die gebied van die wetenskapsteorie was die standpuntinname dat enige handeling voorafgegaan word deur 'n netwerk van faktore. Konkreet beteken dit dat elke optrede of motief deur 'n bepaal-

- Hierdie artikel is 'n voorlopige samevatting van 'n groter projek oor die hantering van etiese dilemmas in die mediese etiek. Die outeur bedank mev Esther Diedericks (UOVS) vir haar indringende deurgaan van hierdie artikel. 
de standpunt wat reeds op hande is, gelegitimeer word. Hierdie insigte het belangrike implikasies vir ons benadering ten opsigte van die hantering van etiese dilemmas.

In hierdie artikel poog die outeur om die resultate van bogenoemde debat sinvol vir die mediese praktyk toe te pas (sonder om die resultate van die wetenskapsteorie volledig te bespreek). Die vertrekpunt word geneem in die apriori-situasie dat konflik (wat beskryf kan word as die botsing van pligte) 'n lewensrealiteit sedert die sondeval is. Omdat ons ten spyte van die toestand op hande steeds verantwoord met ons medemens moet omgaan, word ons gedwing om besluite rakende lewe en dood te neem. In hierdie artikel word die wyse waarop byvoorbeeld die medies-tegniese mag ons besluite beïnvloed, en dus die hantering van konflik, aan die orde gestel. In die daaropvolgende paragrawe word kortliks gefokus op antropologiese kwessies wat ook implikasies vir ons besluitneming en konflikhantering inhou. Die mens as beelddraer van God is maar een voorbeeld hiervan. Ten slotte stel die outeur 'n alternatiewe benadering - 'n kontekstueel genormeerde etiek - vir die hantering van konflik voor, omrede bestaande modelle nie altyd die kompleksiteit van 'n situasie sinvol en genoegsaam kan akkommodeer nie.

\section{KONFLJK: 'N LEWENSREALTEIT}

Uit die digterlike refrein van Genesis 1, 'En God het gesien dit is goed', kan ons aflei dat God 'n goeie en 'n ordelike skepping daargestel het. Weldra sou die mens egter in sonde val. Alle kultuurskeppinge van die mens sou voortaan die merktekens van die sonde dra, dit wil sê dit word gekenmerk deur anti-normatiewe gedrag. Die mens het in onvermoe verval om positief gestalte te gee aan die uitlewing van God se wil vir ons lewens. Ons huidige samelewingsorde (nie te beperk tot 'n bepaalde landstreek nie) word hierdeur gekenmerk. So wys Lasch (1978) daarop dat dit lyk asof die hoogtepunt van die mens se tegnologiese vermoëns saamval met die laagtepunt van sy outonomie - geloof. Volgens Goudzwaard is mense in 'n samelewing wat gekenmerk word deur voorspoed, nie bekommerd oor Bybelse norme nie. Lewensgemak is bepalend ten opsigte van byvoorbeeld aborsie (Goudzwaard 1981: 59). Ten spyte van die feit dat Jesus Christus die werklikheid waarin ons lewe verlos, gaan dit steeds gebuk onder die verwoestende werking van die sonde (Heyns 1982:450). Ons kan dus sonder vrees vir teenspraak stel dat die mens se antinormatiewe handelinge - as gevolg van die sondeval - in direkte konflik én konfrontasie staan met God se wil vir die doen en late van die mens. Dit bring die botsing van pligte te weeg. Keuses moet gemaak word soos byvoorbeeld: Moet lewe ien alle koste bewaar word? Het 'n onomkeerbare komatieuse pasiënt nie die reg om te 
sterf nie? Weeg die behoud van menswaardigheid nie swaarder as die onnodige uitrek van lyding nie? Hier ontstaan 'n botsing van pligte. Dit is wanneer konflik ter sprake kom. In haas alle vertakkings van die samelewing kan ons konfliktendense naspeur. Ook die mediese wetenskap gaan hieronder gebuk. Genoeg om net te verwys na die problematiek rondom die begin (aborsie, proefbuisbabas, ens) en die einde van lewe (genadedood). In terme van die mediese wetenskap het ons hier met grensvrae te doen: Durf die mens 'n besluit oor die lewe van 'n ander neem? Douma (1987:1-2) wys daarop dat sekularisasie én die voortskrydende tegniek verantwoordelik daarvoor is dat mediese boeke 'n nuwe etiek verkondig. Die vraag, Mag ek alles doen wat ek kan doen?, lê aan die wortel van die konflik in die mediese wetenskap. Met al sy medies-tegniese mag blyk dit oneties om alles te doen waartoe die mens tegniese mag het (Smit 1985:206). Of die mens se hart nou deur die Christelike motief of enige afvallige motief beheers word, hy kan hom nóit van hierdie gebroke werklikheid losmaak nie. Alvorens ons aandag gaan skenk aan die hantering van konflik in die mediese wetenskap, gaan ons in die volgende paragraaf eers stilstaan by enkele grondstrukture (-pilare) wat ons hantering daarvan direk beïnvloed.

\section{DIE VRAAG NA BESTAANSEKERHEID}

Gedurende die Middeleeue het die mense 'n hemelverlangende gerigtheid op die hiernamaalse koms van die koninkryk gehad. Die lewe hier benede is bloot beskou as 'n reis na daardie vaderland. Die gelowige moet op hierdie reis kerklik-pastoraal begelei en versorg word (Visagie 1986:32). Die kerk en sy pastorale funksies het 'n konfessionele teken of simbool van sekerheid geword. Juis die oorheersende aard van die kerk oor die samelewing het hierdie taak vergemaklik. Deur die eeue heen is die strewe na die behoud van die versorgende mag in stand gehou; dog dit het nie meer eksklusief in die hande van die kerk gerus nie. Die kerk se pastorale versorging moes plek ınaak vir ánder tekens of simbole van sekerheid. Hierin speel die tegniek, wetenskap en ekonomie 'n leidinggewende rol.

'Die heil van die mens - voorheen bedien deur 'n antisiperende institutêre mag - moet nou gevind word binne die grens van sy werklikheidservaring. In die ontsluiting van hierdie heil is die magte van wetenskap, tegnologie en ekonomie klaarblyklik onmisbare gegewens' (Visagie 1986:33). Hierdie konstituente het nou in die plek van die Middeleeuse magstipe - die verskynsel van pastorale mag - gekom. Die mens het ook veel bygedra om hierdie magstipe van versorgende mag in stand te hou. Naas finansiële sekuriteit het liggaamlike gesondheid toenemend 'n primêre doelwit in die moderne Westerse leefwyse geword. Hier kan ons maar net wys op 
die invloed van die gesondheidskultus en fiksheidsideaal die afgelope paar jaar op die verbruikersmaatskappy. 'Die nastrewe van hierdie ideaal, so word ons meegedeel, beveg nie net siekte, aftakeling en dood nie, maar besorg ook 'n byna transendente ervaring van die "totale welsyn"' (Visagie 1986:37).

In terme van die hermeneuties-simboliese taal kan ons dit so stel: Die mens soek voortdurend 'n simbool van mag om sy bestaansekerheid te beveilig en te waarborg. 'n Dominante simbool binne die konteks van die simbool-universum is die van liggaamlike sekerheid wat die dood ter syde sal stel (en nie net bloot uitstel nie). Die mediese tegniek (wat op sy beurt weer mediese mag in die hand werk) is 'n dominerende simbool wat in die proses van selfhandhawing 'n belangrike rol het om te vervul. Ontwikkelinge op die gebied van die tegniek het die magspotensiaal van die mens vergroot. 'Door de gigantische technische ontwikkeling is de macht van de mens enorm toegenomen' (Schuurman 1985:57). Aan die grondslag van alle tegniese ontwikkeling, lê die beheersingsmotief: '...het motief van de wil tot macht. Religieus gezien is dit geloof in wetenschap en techniek' (Schuurman 1985:44). Dit het daartoe gelei dat die mens 'n vertegniseerde wèreldbeeld nahou: 'dat wil zeggen dat de mens in oriëntatie, motivering en verwachting zich afstemt op wat er technisch allemaal mogelijk is' (Shuurmann 1989:13). Die gevolg was dat die mens in tegnisisme verval het:

Technicisme is de pretentie van de mensdom eigenmachtig heel de werklijkheid met die wetenschappelijk-technische beheersing naar zijn hand te zetten, om op die wijze alle voorkomende problemen op te lossen, en de materiële welvaart en geluk te waarborgen. De mens wil zelf heer en meester zijn, zelf schepper, zelf verlosser en vernieuwer. Het technicisme als een religieuze grondhouding manifesteert zich dus in het 'maakbaarheidsgeloof.

(Schuurman 1989:13)

Dárom beleef die tegniek nie net ' $n$ hoogtepunt nie; maar het dit ook in 'n ideologie $^{1}$ ontaard. As ideologie het dit ' $n$ afgod geword. Goudzwaard (1981:22-24) ken die volgende vyf wesenlike kenmerke aan 'n afgod toe:

- Die wêreld word verselfstandig deurdat dit as heilig en besonders beskou word;

- die wèreld word gepersonifiseer deurdat 'n lewe daaraan toegeken word;

- verering word hieraan toegebring;

- die afgod is 'n redder wat geluk moet voorsien;

- die afgod kry die mens in sy greep.

Die ironie is egter dat die mens aan sy eie maaksel (die tegniek) uitgelewer word. Op sy beurt dra dit daartoe by dat die mens van valse sekerhede en ankers voorsien 
word. Tot op datum kon die mediese tegnologie nog nie daarin slaag om die belofte van 'n onbedreigde liggaamlike sekuriteit te realiseer nie (Visagie 1986:36). O6́k kan dit op datum nog nie daarin slaag om lewe uit niks te skep nie (Lategan 1990a: 37). 'Technology was expected to deliver what it never could: the redemption of life' (Schuurman 1977:21).

Die vermoë van die tegniek is ook innerlik teenstrydig:

Enerzijds zet men alles op met die nieuwste technieken de gezondheid te waarborgen en overschrijdt men in deze verabsolutering van het leven normatieve grenzen, anderzijds roept dit proces een al evenzeer anti-normatieve ontwikkeling op door vanwege de verachting of miskenning van het leven met technische mogelijkheden de dood over de mens uit te roepen.

(Schuurman 1989:20)

Hiermee moet die mens erken dat die misbruik van die tegniek dit iets kreaturrliks gemaak het. Ten spyte van al die positiewe prestasies, hoop wat dit gegee het in baie gevalle waar lewe op die spel was, kan dit nóbit van die mens se sondige hart en dus sy sondige optrede vrygemaak word nie. Die situasie word op die spits gedryf deurdat die mens altyd 'n onvervulde sug na versorgende mag sal hê. Die tegniek het in die ontwikkeling van die mediese wetenskap veel tot hierdie sug van die mens bygedra. Maar tegelykertyd het dit ook 'n offer gevra: Die besluitneming van die mens is voortaan direk hierdeur (onder meer sy tegniese vermoë) beïnvloed. Juis dié toedrag van sake het implikasies vir die hantering van konflik. Die ironie van die saak is dat die konflik intensifiseer namate die vooronderstellings van waaruit ek besluite neem, self nooit van die botsing van pligte (en dus konflik) ontdaan is nie. Prakties beteken dit dat 'n besluit om die botsing van pligte te ontknoop self deur 'n motief wat die botsing van pligte in die hand werk, gelegitimeer word! Ten einde hierdie slaggat mis te trap, behoort die 'bron' van waaruit ons besluite neem, self krities bevraagteken te word. Dit beteken dat solidêr-krities teenoor die tegniek gestaan moet word. Hiermee word gevra na dárdie stand van sake waaruit 'n bepaalde perspektief na vore gebring kan word wat positief waardeer moet word en waarvan elke etikus en/of klinikus gevolglik bevredigende rekenskap sal moet gee, al is dit vanuit 'n alternatiewe teoretiese perspektief.

Ten minste die volgende perspektiewe behoort in die omgang met die tegniek voorgehou te word. Die perspektiewe wat hierin blootgelê word, spel op 'n ondubbelsinnige wyse ons houding teenoor die verband bestaansekerheid en tegniek uit. 


\section{KONFL IK EN ANTROPOLOGIE}

Waarom kan ons nie onvoorwaardelik met lewe omgaan nie? Werk ons met ons etiese beheptheid nie dalk onnodig konflik in die hand nie? Behoort ons altyd ons keuse ten gunste van of selfs ten koste van lewe te regverdig? Juis die nahou van 'n mediese antropologie werp lig op hierdie en ander kontroversiële vrae.

\subsection{Die mens: 'n Beelddraer van God}

Genesis 1:26 wys daarop dat die mens na liggaam en siel geskape is na die beeld en die gelykenis van God. Beeldskap beteken dat die mens God op aarde sigbaar verteenwoordig. Hierdie verteenwoordiging sluit nie God se eie teenwoordigheid uit nie! As beelddraer het die mens 'n status én 'n bestemming in hierdie wêreld (Heyns 1978:125). Beeldskap veronderstel dus 'n amp. Hiervoor eis God dankbaarheid daarvoor, verantwoordelikheid daarmee en eerbied vir ander mense (Heyns 1982:389). Alles wat die mens is en het, behoort aan God (Heyns 1982:366). Daarom moet Christus nagevolg word. Om dit te doen, moet daar geloofsverbonderheid in, geloofsgehoorsaamheid aan en geloofstryd met Christus wees (Heyns 1982:99). Maar wanneer is dit moontlik? 'Die beeld van God word in 'n mens vergestalt wanneer die mens as persoon in sy dinamiese religieuse afhanklikheidsverhouding tot God, kind van God word in Christus en 'n lewe van gehoorsaamheid lei deur onderwerping aan die sentrale liefdesgebod' (Uys \& Smit 1985:8).

Die implikasies wat die beeldskap vir ons oordeel oor die lewe van die mens het, word in die volgende paragraaf bespreek.

\subsection{Eerbied vir die lewe}

In humanistiese kringe word die mening gehandhaaf dat elke individu die reg het om te beslis oor sy eie lewe en dat niemand se menswaardigheid deur seniliteit, pyn, onproduktiwiteit, lyding, ensovoorts afgekraak mag word nie. Liggaamlike kwaliteite is die maatstaf om vas te stel of ' $n$ lewe die 'moeite werd' is om geleef te word of nie. Eerbied vir die lewe word verstaan as die weerhouding van liggaamlike beproewinge. In teenstelling hiermee staan die vitalistiese geloof, naamlik dat lewe ten alle koste behou moet word. Dit ly weer tot onnodige verlenging van lyding. Die mens se lewe is in diens van God, daarom is ' $n$ vitalitiese beskouing van die lewe onaanvaarbaar (Smit 1985:200).

Die Christelike paradigma eis eerbied vir die mens as beelddraer van God. 'Het leven van de mens wordt in de Schrift als een schepping en gave van God gete- 
kend, waarbij de hoge positie van de mens blijkt uit de openbaring, dat de mens naar Gods beeld geschapen is' (Douma 1979a:40).

Douma (1979b:18-19) maak die volgende stellings in verband met die eerbied vir lewe:

- Die mens is eerbied verskuldig aan die Here van die lewe wat beskik oor lewe en dood;

- Die mens het voorwaardelik die reg om lewe in allerlei vorms aan te tas, byvoorbeeld die van plante, diere en mense. Laasgenoemde het te doen met die swaardmag van die staat;

- Die lewe kan soms in diens van God en die naaste opgeoffer word;

- Die mens se lewe kan 'n versadigingspunt bereik. Ons dink hier aan Abraham, Isak, Jakob, Job, ensovoorts: 'en toe is hy (Isak - LL) dood. Hy het gesterf nadat hy oud geword en 'n vol lewe gehad het' (Gen 35:29a).

Ons mag egter nóbit uit die oog verloor nie dat menslike lewe op 'n persoonseenheid van liggaam en 'n religieuse hart dui. In die ontwerp van 'n Christelike antropologie was dit een van die vernaamste hindernisse om van 'n Grieks-dualistiese mensbeskouing bevry te word. In die volgende paragraaf gee ons hieraan aandag.

\subsection{Buitelyne van 'n Christelike antropologie}

Die Woord van God bied nou eenmaal nie aan ons 'n gesistematiseerde mensbeeld nie. Nêrens handel die Skrif opsetlik, sistematies en geordend oor die mens nie. Geen definisie van die menslike natuur word gegee, en geen vaste en skerp afgebakende wese van die mens neem voor ons oë gestalte aan nie. Maar fragmentaries en soms selfs onduidelik word die Bybelleer eerder bewus van 'n dinamiese en gevolglik ondeursigtelike kern wat sy ryke inhoud in 'n oorsigtelike veelheid van situasies en handelinge ontplooi' (Heyns 1978:119).

Daarom sal ons in die lig van die Woord 'n mensbeeld moet konstrueer. Hieruit word dit vir ons duidelik dat daar nêrens 'n tydstip was toe die mens ' $n$ liggaam sonder ' $n$ siel was nie. Dit vorm so 'n eenheid dat die vraag na die aparte ontstaan hiervan volledig vreemd aan die Woord is. 'n Christelike antropologie weerle elke vorm van dualistiese denke oor die mens. Sondigheid is nie gelokaliseer in die liggaam of die siel nie maar in die hart van die mens as die brandpunt of sentrum van sy bestaan. Die vleeslike begeertes' waarvan Paulus praat, het eerder betrekking op 'n hartsgesindheid as 'n minderwaardige liggaam. Christus sê self dat die sonde uit die hart opkom (Matt 7). In die Ou Testament word die hart drie honderd en agtien keer in religieuse konteks gebruik. Die hart kan dus as 'representatiewe 
orgaan', as verteenwoordigend van mens-wees aangegee word (Von Meyenfeldt 1950:152, 214). Die hart stempel die mens as 'n religieuse wese. So staan die mens in 'n religieuse of verbondsverhouding tot God.

Dit blyk dus dat indien ons sou praat van 'n Christelike antropologiese model ons die eenheid van liggaam en siel wat as totaliteit verteenwoordig word deur 'n religieuse hart nie buite rekening kan laat nie. Die effek wat die sondeval hierop het, betrek die onderstaande bespreking.

\subsection{Die verband: sonde, siekte, dood}

Romeine 6:23 kan die suggestie skep dat indien die sondeval nie ingetree het nie, die mens nie sou gesterf het nie. Dieselfde word van siekte gesê. Klassiek is om hier te verwys na die barensnood wat die vrou opgelê is na die val in sonde. In hoeverre kan hierdie stellings gehandhaaf en regverdig word?

Die sonde is wel 'n ramp wat die mens oor homself gebring het. Ons ervaar lyding vanweë die sondeval. Maar, 'n spesifieke sonde kan nie vir 'n bepaalde siekte aangevoer word nie. Wie dit doen, is besig met 'n oorsaak-gevolg verklaring. So 'n verklaringsmodel wys Jesus self af (vgl Joh 9:3 - die verhaal van die blindgebore man). Daar kan wel 'n verband tussen sonde en siekte gelê word (Ps 38:4-5 en Ps 41:5, Louw 1988:76). Lyding is 'n lewensrealiteit. Dit onderstreep die verganklikheid, kortstondigheid, beperktheid en sondigheid van die mens (Pretorius 1984: 26). Liggaamlike ongesteldheid het 'n invloed op die gees en omgekeerd. Daarom handhaaf die psigologie die standpunt dat die fisiologie geken moet word ten einde die invloed daarvan op die psige te verstaan (vgl Louw 1982:41). Cronjé (1965:121) wys daarop dat lyding altyd 'n belewing van die persoonlikheid as geheel is en iets wat ook deur die persoonlikheid as geheel verwerk moet word. Hieruit kan ons dus aflei dat lyding in die vorm van siekte, veroorsaak deur sonde, die mens in sy totaliteit beïnvloed. Die 'totale' menswees kan dus nóbit van die siekte en die sonde losgemaak word nie.

Die vraag word dikwels geopper 'wárom laat God siekte toe?' Hoe moet ons dit verstaan dat God wat 'n liefdevolle God is onmenslike lyding toelaat? Hoe verstaan ons (die teenstrydigheid) dat God lyding nie wil nie maar wel toelaat? Wil Hy met lyding anders as wat die Satan daarmee wil? (vgl Pretorius 1984:49). Ook Louw (1988:76) wys daarop dat God anders by die sonde betrokke is as die mens en die bose:

God is in sy genade en toorn by die sonde betrokke met die oog op die behoud en redding (heil) van die sondaar, die mens is in sy verantwoordelikheid betrokke in die hantering van sy keusevryheid, die bose 
is by die sonde betrokke in die verleiding van die mens ten einde binne die verbondsverhouding 'n breuk tussen God en mens te slaan. Die bose is daardie duistere mag wat op diaboliese wyse God en mens van mekaar wil vervreem. Deur middel van opstand, ilaat, leuentaal, ongeloof en hoogmoed slinger hy die verbondsverhouding uitmekaar en skep hy isolasie en chaos.

Jonker (1982:20) praat dieselfde taal:

Hy laat toe dat hierdie magte van vernietiging in sy goeie skepping woed, sodat die sonde se vrug openbaar kan word. Daarmee is egter nie gesê dat siekte, lyding en dood magte is wat aan die bestuur en regering van God ontruk is nie. God regeer 6́k oor die kwaad en maak dit , téén die bedoeling daarvan in, diensbaar aan sy eie plan en geregtigheid.

Hoe moet ons dit alles verstaan? Dit lyk myns insiens dat ons nie sinvol kan praat oor God se betrokkenheid by hierdie skepping as ons nie ook ideematig ${ }^{2}$ oor Hom praat nie (vgl Strauss 1973:191-195). In terme hiervan sal ons God se 'wilsbetrokkenheid' by voorbaat moet afwys. Wat beweeg God om uit Homself en sy niksbehoewende algenoegsaamheid te tree en 'n wêreld buite Homself te skep en dan daarby betrokke te wees? Meestal word die antwoord gegee as die ondeurgrondelike Goddelike wil of welbehae wat in die eerste plek op die handhawing van die glorie van God gerig is. Dit verklap egter die ongespesifiseerde wyse waarop dikwels oor God se wil gepraat word, naamlik dat 'n deel daarvan geopenbaar is en die res is verborge. In sy wese gryp sodanige argumentvoering terug na 'n Griekse duiding van sigbaar en onsigbaar. In hierdie sogenaamde 'teo-ontologiese model'3 skuil 'n 'wese' agter die 'verskyning'. Konkreet beteken dit dat indien die Woord sê dat God liefde is, dit nie beteken dat daar agter hierdie openbaring van God 'n onkenbare wese skuilgaan wat nie aan ons geopenbaar is nie. Hiermee word geimpliseer dat die Woordopenbaring dan slegs 'denkbeeldig' is. Op sy beurt weer ondergrawe dit die gesag van die Woord. In sy liefde oorskry God die grense van ons begripsvorming. God is die liefde wat Hy se Hy is, ongeag hoe Hy daarin ons beperkte begripsmoontlikhede oorskry. Daarom kan ons hierdie verhewe geopenbaarde liefde van God slegs ideematig benader sonder dat ons dit 66 it begripsmatig kan omvat.

Watter implikasies het dit vir ons vraag: 'Hoe is God by siekte en lyding betrokke?' Hierop kan ons die volgende antwoord: God openbaar sy liefde aan en sy behoud van die 'gekruisigde' sondaar. Ten spyte van die gebrokenheid van hierdie skepping is God dinamies én aktief hierby betrokke deurdat Hy die religieuse dood vernietig het ${ }^{4}$ en die 'gekruisigde' sondaar help om teen lyding te protesteer (protes 
motief), rebelleer maar ook te terapeutiseer. Terapie bedoel hier om die bose altyd met die goeie teen te staan (en te vervang). Dit loop uit op die berustingsmotief wat alleen in algehele oorgawe aan God verkry kan word.

Ten slotte moet ons ook aandag aan die vraag gee of die dood die loon van die sonde is. Ongekwalifiseerd kan 'n mens hierop ja antwoord. Dit is egter 'n valse aanname. Om te sê iemand is dood, kan verskillende betekenisinhoude hê. Hier kom die verskillende oomblikke van dood ter sprake. Die mens sterf onder meer 'n biotiese, juridiese, religieuse dood, ensovoorts. Biotiese dood het te doen met die doodgaan van die fisiese liggaam. Juridiese dood tree in nadat die geneesheer 'n doodsertifikaat uitgereik het. Wie religieus sterf, ontbeer die teenwoordigheid van sy God. Wanneer die gelowige religieus sterf, dan sterf hy buite Christus. Hier is dit dan nie net die liggaam en die siel wat sterf nie, maar die Godsverhouding. Hieruit kan ons aflei dan die sondeval nie die (fisieke) mens met verganklikheid beklee het nie, maar dat dit nou die moontlikheid gelaat het dat die mens religieus kan sterf. Sonder 'n sondeval sou die mens wel bioties sterf; dog nie met dieselfde lyding nie (vgl Lategan 1990a:37-40). Die sondeval het niks aan die orde van die skepping kom verander nie. Lewe en dood behoort tot die orde van die skepping. Die ellende wat hiermee gepaard gaan, is te wyte aan die sondeval. Geboorte- en sterwensnood het na die sondeval die kreatuurlike belewenis van lewe en dood geword.

\subsection{Etiese, juridiese en teologiese vrae rondom die neem van 'n lewe.}

Die staat is 'n regsverband wat onder leiding van 'n publieke geregtigheidsidee onderdaan en owerheid moet saambind. Die staat besit 'n juridies-begrensde regsmag en derhalwe 'n begrensde gesagsbevoegdheid. Reg en mag domineer die staat. Elke lewensvorm in die gedifferensieerde samelewing word gekenmerk deur verskillende soorte magsvorming, afhanklik van die kwalifiserende funksie van die lewensvorm waarin dit aangetref word:

The monopolistic organization of the power of the sword is the only typical form which is not found as a foudational function in any of the other differentiated social structures. The other forms of power, insofar as they are really internal forms of State-power, are themselves only intelligible from the structure principle of the body politic, which implies a monopolistic military organization as its typical foudational function.

(Dooyeweerd 1984:416-417) 
Op grond van die kwalifiserende regsaspek van die staat is die owerheid geroepe om ewewig en harmonie in 'n veelheid van regsbelange te handhaaf. Die nie-staatlike owerheidswerk kan alleen regverdig word wanneer dit beskawingsmondigheid bevorder. Dít kan alleen plaasvind indien dit onder leiding van Christelike beskawingsnorme geskied. In hierdie geval kan die staat dan ook optree teen die niestaatlike owerheidsintellings wat beskawingsverval in die hand werk. Daarom is dit die prerogatief van die staat om te beslis oor die neem van 'n lewe. So bepaal die wetgewer dan dat die wederregtelike neem van 'n lewe met die dood strafbaar is, mits versagtende omstandighede nie aangevoer kan word nie. Die howe oefen dan ook alleen sy regterlike funksie uit oor 'n konkrete geskil wat van daadwerklike belang vir die werklike partye is (Strauss 1982:14). Die hof laat hom lei deur die maatstaf van goeie sedes, die boni mores. Regter Mostert se verduideliking in die saak Universiteit van Pretoria v Tommie Meyer Films (Edms) Bpk werp lig hierop: 'Onregmatigheid word basies aan die hand van die boni mores bepaal. Deur die maatstaf van die "regsoortuiging van die gemeenskap"...toe te pas, verkry die regstelsel die voordeel van die wisselwerking van die ethos en geregtelike voorbeeld, en 'n soepelheid wat by meer presedentgebonde stelsels ontbreek'.

Joubert (1953:146) se siening verdien ook ons aandag: '(dit gaan hier om) die onuitputlike behoorlikheidsbeginsel van ons gemenereg...(wat)...oor die belange van individu sowel as gemeenskap...wakk...(waar)...die kasuïstiek dan swygend is ook oor die aanspreeklikheids- of onregmatigheidsgevolge van 'n besondere gedraging, word dié algemene maatstaf toegepas'.

Die Woord (by name die sesde gebod) verbied nie alle doding nie. Slegs die wederregtelike (onwettige), daarom onbevoegde doodmaak van 'n mens sonder dat die Here so 'n opdrag gee, word verbied. Dit gaan dus hier om dood as moord en nie die dood as straf nie, want onskuldige bloed word vergiet. Die Hebreeuse werkwoord rasah word in Eksodus 20:13 gebruik. Hier het dit betrekking op opsetlike doodslag. Vir dood op juridiese grond of in 'n oorlog word harag en naka gebruik (Fensham 1970:138, vgl ook Douma 1979a:44-45).

Uit hierdie gegewens kan ons aflei dat die Woord die wederregtelike neem van die ontwikkelde en die kwynende lewe verbied. Sowel die reg as die Woord appelleer op die positivering van die beginsel dat geen lewe wederregtelik geneem mag word nie. Die Wet-Woord 5 waardeur Christus die werklikheid in stand hou, suggereer altyd 'n toestand van orde. In ordelikheid moet die mens in die skepping bestaan. Daar bestaan altyd ruimte vir die positiewe hersiening en konkretisering van beginsels. 


\section{DIE MINDERE VAN TWEE EUWELS': 'N VERSOENINGS METODOLO- GIE VIR KONFLIKSITUASIES}

Die klinikus word voortdurend voor etiese keuses gestel. Enige keuse verg sinvolle en verantwoordelike optrede juis omdat 'n netwerk van invloede (par 3) en die religieuse status van die mens (par 4) eventueel implikasies vir ons besluite inhou. Met dít in gedagte word 'n etiese model 'Die mindere van twee euwels' voorgestel as 'n moontlike diskoers om konflik in die mediese wetenskap eties te hanteer. Die volgende twee paragrawe toon argumente hiervoor aan.

\subsection{Etiek, konteks, optrede}

Die situasie-etiek het ons geleer dat die konteks (situasie) bepalend is vir die norm. Hierdie standpunt kan nie genoegsaam beklemtoon word nie. Die situasie-etiek het egter oordrewe aksent op die liefde geplaas. Alles kan in die naam van die liefde regverdig word. Konkreet leer dit dat om met die ambassadeur in die bed te klim ten einde geheime uit te vind - vaderlandsliefde is. Klim jy saam met die busbestuurder in die bed - dan is dit prostitusie. Die Rooms-geïnspireerde kasuistiek leer dat elke geval 'n reël het. Die onverbiddelike nakoming hiervan word geëis. So geld die reël dat alle seksuele kontak moet geskied met die oog op die verwekking van kinders. Derhalwe word alle kontrasepsie byvoorbaat afgewys. Aborsie is ook ontoelaatbaar; ongeag of die volhou van die swangerskap die moeder en/of die ongebore kind se lewe bedreig. Van die uniekheid van elke situasie is hier geen sprake nie. Vergelyk hierdie uitspraak: 'A person who actually procures an abortion incurs a latae sententiae $e^{6}$ excommunication' (The cade of the canon law 1984:1398).

Die probleem met beide etiese benaderings is dat een beginsel bo al die ander uitgelig word en dan as norm verhef word. Die korrekte benadering is dat geen beginsel voorrang bo ' $n$ ander geniet nie. Juis deur verskillende beginsels in ag te neem, slaag ons daarin om diverse beginsels in harmonie met mekaar te stel. As korreksie hierop stel ek 'n Reformatoriese benadering voor. 'n Reformatoriesetiese optrede gryp terug na die beginsels wat deur die kosmiese skeppingsorde of wetmatigheid van God weerspieël word. Vir die menslike lewe is modale en strukturele voorwaardes daargestel. Die mens leef kragtens hierdie skeppingsbeginsels. In sy omgang hiermee positiveer (maak tot gelding) die mens uit die beginsels norme. Norme kan beskou word as gepositiveerde beginsels vir die uniekheid van elke situasie. Die daadwerklike uitleef van 'n beginsel kan alleen geskied teen die agtergrond van die sluit van kompromieë, waarna 'n mens ook kan verwys as die 'mindere van twee euwels'. 'n Dinamies-gepositiveerde optrede vereis die aangaan van kompromieë. Die bedoeling van die kompromie is nie om die situasie op te hef 
nie, maar juis deur die situasie te kontinueer ongeag die hesondere dilemma. In geval van 'n kompromie is daar nie sprake van 'of...of' nie maar wel van 'en...en'. Die kompromie duik dus in situasies op waar die gelyktydige uitvoer van twee of meer pligte of belange eenvoudig nie moontlik is nie. Die gebrokenheid van die skepping aksentueer die belang van die kompromie. Oor die hantering van 'n dilemma, stel ons Heyns (1982:385) aan die woord.

Die blote feit dat die mens voor verskillende keuses geplaas word, en dat hy dit as 'n botsing van pligte beleef, is al 'n bewys dat ons in 'n gevalle wêreld lewe (1 Joh 5:19). Daarmee is dit ook - vanselfsprekend - gegee die moontlikheid én die werklikheid van foutiewe beslissinge en die daarmee noodwendig gepaardgaande worsteling en lyding.

Heyns (1982:384) meen verder '...dat ons hier inderdaad met ' $n$ botsing van pligte te doen het, met ander woorde 'n botsing van teenstrydige opdragte wat God die mens oplè:.

Waar hy meen dat alle alternatiewe euwels inhou, sal hy die minste van die euwels moet kies wat die minste skade en die minste nadelige effek sal hê, maar die meeste liefde en die meeste geregtigheid beliggaam....By al die smart en droefheid oor soveel onvolmaaktheid ook in die allerbeste bedoelinge en met die erkenning van persoonlike skuld aan soveel ongeregtighede, leef die gelowige steeds in die oortuiging dat hy op die vergifinis van God mag reken en dat ook sy kompromiehandelinge deur Hom ten goede gebruik sal word....Anders en beter gesê: in die kompromiesluitende handelinge van die mens lewer hy die bewys dat hy mens is na die beeld van God wat vrolik voort mag lewe.

(Heyns 1982:451-452)

Kompromiesluitende handelinge vorm in wese die kern van 'n versoeningsmetodologie wat veral handig binne die konteks van 'n bepaalde dilemma benut kan word. Die sake waaraan aandag geskenk moet word is:

- Wat is God se wil vir die kliniese praktyk?

* Moet God se wil onder alle omstandighede bewaar word?

- Die sluit van kompromieë.

In ons bespreking van God se wil het ons daarop gewys dat God ideematig benader moet word omdat ons begripsmatig alléén, niks 'positief' oor hom kan sê nie (vgl par 4.4). Ons het ook tot die gevolgtrekking gekom dat indien God deur sy wil 'oor- 
heers' word, God inderdaad aan 'n mag groter as Hyself onderworpe is! In die ideematige benadering van God word dit duidelik dat hoewel die implikasies van sy wil ons begripsvermoe oorspan, ons wel reeds begripsmatig kan sê dat God altyd 'n toestand van ordelikheid suggereer. Die gebrokenheid van die skepping is te wyte aan die sondige afvalligheid van die mens se rigtingkeuse wat sondige merktekens op sy kultuurhandelinge in die skeppingsverskeidenheid laat. Dit is dan inderdaad ook hierdie onvermoë van die mens om ordelikheid te handhaaf wat tot gevolg het dat die botsing van pligte veroorsaak word. Die Christen wat in beginsel nie meer sondig nie (maar konkreet wel) gaan juis die sluit van kompromieë aan om 'n toestand so na as moontlik aan ordelikheid te handhaaf. Juis die uniekheid van elke situasie wat appelleer op die dinamika van die gepositiveerde beginsels kan onmoontlik die gebod áltyd handhaaf. Die teologie is in beginsel dit wel eens dat 'n skopus vir elke tyd 'n eiersoortige betekenis het; dog die interpretasie van elkeen verskil. Die bewaring van die gebod beteken immers om te vra na die beginsel daarvan.

Bewaring van die wet deur die gelowige beteken dat hy by geleentheid ook die grense van die geopenbaarde wet sal oorsteek in sy poging om Gods wil te gehoorsaam. Die wet is natuurlik Gods wil, maar die volledige openbaring en volledige formulering van Gods wil vir alle moontlike lewensituasies, vind ons nie in die wet nie. Om Gods gebod te gehoorsaam beteken dat die mens in die geloof verder sal vra en verder sal soek na Gods wil, verder sal dink en formuleer. Bewaring van die wet is nie, 'n passiewe ontvanklikheid of 'n blote repetisie nie, maar ook 'n aktiewe skepping. Dit is 'n wandel in wysheid (Ef 5:15), 'n onderskeiding van die dinge waarop dit aankom (Fil 1:10) 'n bede om verstand (Ps 119:34).

(Heyns 1982:304)

Elke konkreet-unieke situasie word gerugsteen deur die sentrum van die wet, naamlik religieuse liefde. Die gemeenskaplike drakrag wat in elke gepositiveerde beginsel gehandhaaf moet word, is 'n agape-eerbiediging vir die naaste maar ook die self: -...the agape relationship....allows the other person to appear, not merely in his being, his "being as he is", but rather in his "being before God"' (Thielicke 1981:27).

Elke kompromie-sluitende handeling moet geneem word vanuit die religieuse hart as die sentrum van die mens se bestaan. Dit moet met volle inagneming van die 'status' van die mens geneem word. Dit behels die vrae waaroor ons reeds gehandel het, byvoorbeeld beeldskap, antropologie, die verband sonde-siekte ensovoorts (kyk par 4). Die keuse vanuit die religieuse hart verdien besondere aandag juis omdat ons keuses in 'n groot mate deur die vooronderstelling van sekere kultuurmagte soos byvoorbeeld wetenskap, tegniek en ekonomie beinvloed word. Die 
ideologiese kante hieraan verbonde en die wyse waarop dit ons keuses bemvloed, is hierbo reeds bespreek (kyk par 3). Elke keuse wat geneem word, behoort krities bevraagteken te word. Hiervoor word 'n bepaalde sensitiwiteit voor opgeëis. Wie alleen die eensydigheid van die gesindheid waarin iets gedoen word, vooropstel ten koste van die daad self of die gevolge wat 'n bepaalde optrede mag meebring, beoefen 'n eensydige gesindsheidsetiek. Die gesindheid regverdig alles. Dit bring die obseniteit mee dat ek met liefde kan doodmaak! Wie slegs 'n doeletiek beoefen, verkondig daarmee die slagspreuk: die doel heilig die middele. So sal die 'kweek' van kinders met drie 'koppe' eties geregverdig wees omdat die daad om wetenskaplike redes uitgevoer word. Ook die eensydigheid van hierdie benadering staan voorop. Dit is dus voor-die-hand-liggend dat benewens die daad self ook die gesindheid sowel as die gevolge in 'n etiese beoordeling in ag geneem sal word. Hiervoor skep die kompromie voldoende ruimte.

\section{6. 'N KONTEKSTUEEL-GENORMEERDE ETIEK}

Paragraaf 5 het die breë raamwerk van 'n etiese kode, die sogenaamde 'mindere van twee euwels' geskets. Meer gerafineerd kan ons in etiese-jargon hierna verwys as die wese van 'n kontekstueel-genormeerde etiek. Dié etiese benadering is 'n Reformatoriese uitgang wat in reaksie kom teen die eng dogmatisme van die kasuïstiek en die verfynde humanisering van die situasie-etiek. Kernagtig kan die 'embrionalebetekenis' hiervan só saamgevat word: Die mens is 'n religieuse wese. Vanuit sy religieuse hart maak hy 'n apo- of diastatiese keuse met betrekking tot God. Die mens se werklikheidsbelewenis beïnvloed - positief of negatief - die keuses wat hy moet maak.

Die gebrokenheid van die skepping en die afvallige keuseposisie van die mens bring 'n botsing van pligte mee. Om 'n keuse uit te voer, word 'n appèl gemaak op die dinamika van die beginsels wat as skeppingsbeginsels gepositiveer moet word. Elke (etiese) situasie is uniek. Alleen riglyne en nie antwoorde nie vir optrede, bestaan. Ons het geen waarborge nie; daarom moet ons keuses maak.

Die 'riglyne' ( $6 \mathrm{f}$ bèginsels) word nie deur die situasie bepaal nie, maar die Woord gee beginsels wat in elke situasie sinvol uitgeleef kan word. Afvallige rigtingkeuses wat meestal in ideologieë manifesteer, verduister die hart en dus die optrede van die mens.

Hierdie model kan ons dus so saamvat: Teen die agtergrond van Christelike (en nie Biblisistiese) beginsels moet elke situasie eers binne die bepaalde konteks verreken word, waarna die beginsels wat betrekking op die situasie het, gepositiveer word. In feite behels dit 'n kompromie-sluitende handeling of dan die mindere van 
twee euwels. Omdat die mens geen outomaat is nie het hy beginsels waarbinne hy lewe (positivering). Sowel die daad as die gesindheid moet ten volle in ag geneem word in ons etiese beslissings.

Dit deug byvoorbeeld nie om te dink in terme van 'n situasie-etiek en dan waar nodig ' $n$ bietjie 'beginsels' by te voeg nie. Omgekeerd kan ewe min gedink word in terme van strakke (vir alle tye en vir elke situasie klaar gepositiveerde) beginsels, wat dan aangevul word deur hier en daar die situasie 'n woord te laat meespreek. Positief moet ons stel dat álle menslike handelinge altyd konkreet en situasie-gebonde is en tegelyk altyd niks anders as genormeerd is nie. Elke situasie word trouens eers moontlik gemaak deur die grondliggende normatiewe struktuur daarvan.

\section{Eindnotas}

1. Die kosmiese wetsorde van God vertoon 'n onderskeiding van struktuur en rigting. Die rigtinggrens veronderstel die antitese tussen diegene wat deel het aan die uitverkore volk van God en hulle wat nie daarin deel nie. Dit verwys na die RST-dimensie van skepping (dit is die dimensie waar radikale, sentrale en totale verbintenisse aangetref word) en die struktuuronderskeid as die GPGdimensie betref verbintenisse wat gedifferensieerd, periferiaal en gedeeltelik van aard is. Die GPG-dimensie vertak vanuit die RST-wortel en dui op die veelheid relasies waarin die mens gedifferensieerd kan bestaan. 'n Ideologie ontstaan wanneer wortel (RST) en tak (GPG) verwissel word. 'n Ideologie is dus 'n oorkoepelende en alles omvattende ideekompleks wat die mens dwing om sy bestaansekerheid daarin te vind. Uiteraard tipeer ek ' $n$ ideologie dus as 'n negatiewe verskynsel omrede dit 'n eie gemaakte messiaanse verwagting aanbied as rusoord vir die soekende mens.

2. Wanneer modale terme gebruik word om gegewens aan te dui wat binne die grense van 'n bepaalde aspek voorkom, het ons met 'n begripsgebruik te doen. Indien modale terme daarenteen gebruik word om na gegewens te verwys wat die grense van die betrokke aspek te bowe gaan, het ons met 'n ideegebruik van die betrokke term te doen.

3. Meer volledig oor die wil van God en 'n teo-ontologiese model kan nagelees word in Lategan (1990b:116-118).

4. Ons kom later in die hierdie paragraaf op hierdie term terug.

5. Die gestalte van die Wet-Woord mag nie verskraal word tot die tien gebooie of die Mosaïese wette nie. Kuyper (1909:463) wys daarop dat ons 'niet alleen aan die tien geboden; ook niet enkel aan de Mosaïsche wet, of de wet der zeden en ceremoniën denke; maar dan moet zich voor uw oog dat gansche samestel van 
wette in al het creatuurlijke vertoonen, waardoor als wat God schiep, op die aarde, boven die aarde en onder de aarde, bestant'. God se Wet-Woord verwys na God se Skepperswil vir al sy skepsele. Hoewel verwys kan word na Gods Woord vir ons ekonomiese, juridiese en estetiese lewe, word die Wet-Woord as algemene spreekwyse ingespan om die skepperswil in die onderskeie skeppingsterreine aan te dui, sonder om gespesifiseerd hieroor te praat.

6. The term to describe one of the two forms of penalty, namely, that which is automatically incurred on committing an offence, without the intervention of a judge or superior' (The code of Canon law 1984:319).

\section{Literatuurverwysings}

Cronje, G 1965. Mens tot medemens. Kaapstad: HAUM.

Dooyeweerd, H 1984. A new critique of theoretical thought, Vol 3. 3rd edition. Ontario: Paideia Press.

Douma, J 1979a. Abortus. Amsterdam: Uitgeverij Ton Bolland.

- 1979b. Euthanasie. Groningen: Uitgeverij De Vuurbaak.

--- 1985. Mediese etiek. PU vir CHO: Instituut vir Reformatiese Studies.

Fensham, F C 1970. Exodus. Nijkerk: Callenbach.

Fletcher, J 1976. Situation ethics. London: SCM.

Goudzwaard, B 1981. Genoodzaakt goed te wezen. Kampen: Kok.

Heyns, J A 1978. Dogmatiek. Pretoria: NGKB.

- 1982. Teologiese Etiek, 1. Pretoria: NGKB.

Joubert, W A 1953. Grondsake van die persoonlikheidsreg. Kaapstad: A A Balkema.

Kuyper, A 1909. E Voto Dordraceno, Vol 3. Kampen: Kok.

Lasch, C 1978. The culture of Narcissism: American life in an age of diminishing expectations. New York: Norton.

Lategan, L O K 1990a. Die mag en die onmag van die mediese wetenskap. RSA Verpleging 5/1, 37-40.

Lategan, L O K 1990b. Kritiese perspektiewe op die teologiese ontwerpe van J A Heyns. Tydskif vit Christelike Wetenskap 1/2, 105-120.

Pretorius, W W 1984. Die aspek van sinvinding in die pastorale gesprek. MThverhandeling, UOVS.

Schuurman, E 1977. Reflections on the technological society. Ontario: Wedge Publishing Foundations.

- 1985. Tussen technische overmacht en menselijke onmacht-verantwoordelijkheid in een technische maatschappij. Kampen: Kok. 
Schuurman, E 1989. Wijsgerig-ethische achtergronden van de genetische manipulatie. Tydskrif vir Christelike Wetenskap 1/2, 12-24.

Smit, J H 1985. Etos en etiek. Bloemfontein: Patmos.

Strauss, D F M 1973. Begrip en idee. Assen: Van Gorcum.

The code of canon Law. 1984. 5th print. London: Collins Liturgical Publications.

Thielicke, H 1981. Theological ethics, Vol 3. Grond Rapids: Eerdmans.

Uys, L R \& Smit, J H 1985. Kliniese etiek. Kenwyn: Juta.

Van den Berg, J H 1985. Medische macht en medische ethiek. Nijkerk: Callenbach.

Visagie, P J 1986. Versorgende mag. Tydskrif vir Christelike Wetenskap 1/2, 32-39.

Von Meyenteldt, F H 1950. Het hart (Leb, Lebab) in het Oude Testament. Leiden: Brill.

\section{Hofsaak}

Universiteit van Pretoria v Tommie Meyer Films (Edms) Bpk. 1977 (4) SA 376 (T). 